\title{
Mediating Role of Liquidity Policy on the Corporate Governance-Performance Link: Evidence from Pakistan
}

\author{
Safdar Husain TAHIR ${ }^{1}$, Muhammad Abu Bakar SADIQUE ${ }^{2}$, Nausheen SYED ${ }^{3}$, Faiza REHMAN ${ }^{4}$, \\ Muhammad Rizwan ULLAH ${ }^{5}$
}

Received: April 18, 2020 Revised: May 31, 2020 Accepted: July 07, 2020

\begin{abstract}
Based on the theoretical underpinnings of the agency theory and liquidity theory, the purpose of this study is to show how managers who want to enhance the performance of Pakistan's non-financial sector can use liquidity policy in relation to corporate governance. Nowadays, Pakistan is facing a severe liquidity crisis; this study contributes by examining the mediating role of liquidity on the link of corporate governance-performance. We use data from 63 firms from 2010 to 2018, excluding 17 outliers. To analyze the data, we use the Seemingly Unrelated Regression (SURE) model and nlcom-Stata test. Our findings support the mediating role of liquidity on the link between corporate governance and performance. In addition, the results show that corporate governance improves performance. Furthermore, the study supports a significant positive association of liquidity and performance. For robustness, we use two performance variables - return on assets (ROA) and Tobin's q (TQ) - where ROA represents full mediation and TQ indicates partial mediation. This study helps to use liquidity policy to strengthen the inside and outside dimensions of corporate governance mechanisms that improve the performance of firms. Overall, these findings suggest better disclosure, transparency, and solutions to auditing issues that add value to the firms.
\end{abstract}

Keywords: Corporate Governance, Liquidity, Performance, Mediation, Nonfinancial Firms

JEL Classification Code: G31, G34, J52, O16

\section{Introduction}

In emerging economies like Pakistan, good governance has been a hotly debated issue for decades. This has become important in the eyes of the international community

${ }^{1}$ First Author and Corresponding Author. Associate Professor, Lyallpur Business School, Government College University, Faisalabad, Pakistan [Postal Address: Officer Colony-2, Madina Town, Faisalabad, 38860, Pakistan] Email: drsafdargcuf@gmail.com

${ }^{2}$ Research Scholar, College of Commerce, Government College University, Faisalabad, Pakistan. Email: abu.baker718@yahoo.com

${ }^{3}$ Assistant Professor, Business Administration, Government College Women University, Faisalabad, Pakistan. Email: nausheen@gcwuf.edu.pk

${ }^{4}$ Lecturer, Public Administration, Government College Women University, Faisalabad, Pakistan. Email: faizarehman@gcwuf.edu.pk ${ }^{5} \mathrm{PhD}$ Scholar, Lyallpur Business School, Government College University, Faisalabad, Pakistan. Email: mrizwanullah77@gmail.com

(c) Copyright: The Author(s)

This is an Open Access article distributed under the terms of the Creative Commons Attribution Non-Commercial License (http://Creativecommons.org/licenses/by-nc/4.0/) which permits unrestricted noncommercial use, distribution, and reproduction in any medium, provided the original work is properly cited. after the major crises in Britain and the United States in 1970 and 1929, respectively (Porter, 1992). In Pakistan, the issue of corporate governance began to arise in 1958 and the government took the initiative in 1980 when the Pakistani government joined the International Monetary Fund, which is bound by a number of conditions related to socio-economic and political developments. The biggest governance crisis is in Pakistan, especially in the nonfinancial sector, with power shortfalls in all industries. In 2008-16, Pakistan experienced severe power shortfall of 18 hours in rural areas and 8 to 12 hours daily in urban areas (Valasai et al., 2017). Major factors behind this shortfall are electricity demand, lack of energy resources, financial constraints, and governance issues (Pervez \& Sohail, 2014). This scenario creates a liquidity crisis in industries, especially in the manufacturing and non-financial sectors. Therefore, the study addresses very important issues and seeks to offer some feasible and practical suggestions to management compensating for performance, engaging the mediating role of liquidity, rare in the history of research on Pakistan. 
Liquidity refers to the ability of an organization to meet short-term obligations using resources such as cash, marketable securities, account receivables, and inventory. Different resources provide different levels of liquidity. For example, inventory is considered a liquid resource that may not be as liquid as other liquid assets. Liquidity management refers to the manager's ability to generate cash from the process that meets the firm's current needs. The study investigates this ability in the context of codes of corporate governance in connection with firm's performance as it may mediate the link within liquidity constraints. Liquidity constraints on a firm's investment decisions are a major issue in economic research (Lin, Hu \& Chen, 2003). The liquidity constraints related to investment decisions of a firm is the core issue of economic research (Lin, Hu \& Chen, 2003). Previous literature finds that limited resources could be identified by the degree of asymmetric information, linked with governance structure such as pay-out ratios, firm size, firm age, bond rating, membership in financial conglomerates, and degree of bank relation (Hobdari, Jones \& Mygind, 2010).

In implementing operational activities, management will need to maintain a level of liquidity, not a small amount or a large amount that could negatively affect performance. Being profit-oriented, a company requires efficiency in operations to be able to improve its performance (Bokpin \& Arko, 2009). The success of good corporate governance depends on internal and external factors. In addition, these factors are related to the integrity, credibility, expertise, and quality of the various stakeholders that drive the business organization. The implementation of regulations in the context of good corporate governance should not ignore other factors such as liquidity, disclosure and other stakeholder information, which reinforces the company's existing strategy in line with its vision and mission.

The research study presents new evidence of this subject, which should attract researchers, practitioners, manufacturers and managers, but for whom there is less empirical research about the mediating role of liquidity between corporate governance and firm's performance. The article contributes significantly to the contemporary literature in many ways. First, it seeks to examine the performance of management as a mediating role, which is rare in the literature. The relation between governance and corporate performance has already been proven (Bhagat \& Bolton, 2008), but testing the mediating role is a contribution. Second, the study opens the debate in the corporate governance literature through the role of liquidity. Last, the analysis of the study allows to answer an important question: How can liquidity be used to increase performance under the umbrella of good governance practices?

The remaining part of the study is organized as follows. Section 2 presents a theoretical as well as empirical review of literature with the conceptual framework. Section
3 explains the research methodology, measurement of variables, econometric models and estimation methods. Section 4 illustrates statistical description, empirical findings and regression results. Section 5 and 6 end the paper with discussions, limitations of study and future research.

The following are the research objectives:

- To examine the governance-performance linkage of the non-financial companies.

- To analyze the mediating role of liquidity on the governance-performance relation of the non-financial companies.

- To substantiate the liquidity-corporate governance link of non-financial companies.

- To investigate the connection of liquidity-performance of non-financial companies.

\section{Literature Review}

\subsection{Agency Theory}

The agency theory presented by Jensen and Meckling (1976) describes that the principals (shareholders), who are actual proprietors of organizations, entrust the operation of the corporation to the agents (managers). As per owner's thinking, the managers should work in the best interest and greatest advantage of the firm. Their decisions should improve the firm's performance and create value. Conversely, the attention of managers might deviate from principals. This inconsistency between the principal and agent creates the agency cost. Therefore, the agency theory discusses the agency cost and the ways to diminish it for an organization (Paminto, 2015).

\subsection{Asymmetric Information Theory}

George (1970) applies the asymmetric information in his composition "The Market for Lemons". In this theory, governance practices have an effect on liquidity for the reason that solid governance expects to increase transparency, which decreases information asymmetry and resolve the auditing issues. When information asymmetry is not severe, liquidity sources face less adverse selection complications. As a conclusion, organizations with greater governance will probably exhibit additional equity liquidity (Prommin, Jumreornvong, \& Jiraporn, 2014).

\subsection{Empirical Review}

Kabir, Aripin and Al-Dhamari (2019) contemplate the hypothetical relationship of liquidity with a level of good governance practices of companies and financial performance. The purpose of their research was to affirm a relation among the governance attributes, other organizational 
mechanisms including firm's value, and financial liquidity. Research findings by Achim, Borlea and Mare (2016) show a significant and direct relationship between governance of companies and liquidity. It was because efficient governance would reduce the liquidity issues like the right information to stakeholders, disclosure and transparency. Some other research studies (Tang \& Wang, 2011) find a strong linkage between implementation of codes of corporate governance and liquidity by using cross-sectional data of Chinese stock markets. Their analysis of the corporate governance's subindices also supported the direct connection between the governance of companies and firm's liquidity.

Similarly, some research studies (Khidmat \& Rahman, 2014) establish an association between good governance practices and firm's performance. These research studies use many factors and ratio analyses of liquidity, solvency, profitability, and asset utilization, but their results were contradictory (Muhammad, Rehman \& Waqas, 2016). For instance, Akben-Selcuk (2016) studies the factors that are expected to influence the firm's competitiveness. He finds a significant relation between Tobin Q and liquidity level. Similarly, Rajangam, Senderasen and Rajagopalan (2014) verify the influence of corporate governance on different factors including profitability, liquidity, and gearing ratios.

Nguyen, Pham and Nguyen (2020) find strong correlation between liquidity and profitability. In addition, he indicates that liquidity facilitates higher performance. In another study conducted by Omondi and Muturi (2013), with extensive analysis, provided more insights into the association between corporate performance and liquidity. Similarly, a study conducted by Lamberg and Valming (2009) established insignificant link between return of assets and liquidity strategies. They use liquidity positions in relation to performance by explaining whether changes in the firm strategy of liquidity would result in any changes to the profitability of the corporation.

Brown and Caylor (2006) investigate the association between the governance of company and its valuation. Their findings recommend that higher company's governance improve valuation. Dundek, Klacmer and Detelj (2017) state after extensive analysis that good corporate governance is essential for improving the value of corporations by using data from Zagreb stock exchange (ZSE). Prommin, Jumreornvong, Jiraporn and Tong (2016) test the connections between liquidity, ownership and company`s governance in emerging markets. They explore those corporations with active ownership experience extensively decreasing liquidity. Shareholders assume that asymmetric information incurs higher expenses of firms, which reduce value. On the other hand, there is no evidence of association between ownership and liquidity. Drawing from theoretical and empirical reviews of literature, the hypotheses are framed as below:
$\mathrm{H}_{1}$ : There is a substantial linkage between the governance of companies and performance

$\mathrm{H}_{2}$ : Liquidity of a firm mediates the relation between governance of companies and performance

$\mathrm{H}_{3}$ : There is an association between corporate governance of a company and its liquidity policy.

$\mathrm{H}_{4}$ : There is a linkage between adequate liquidity and performance of companies

\subsection{Theoretical Framework}

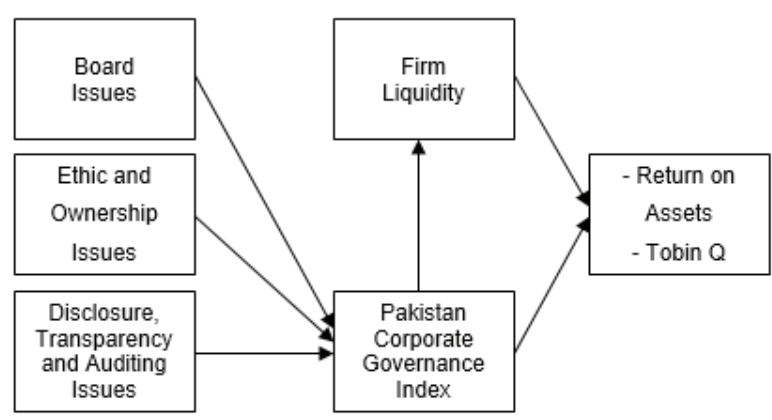

Figure 1: Conceptual Framework

\section{Research Methodology}

The research goals of this article are to identify the role of liquidity on the relation between governance of a company and firm's performance. In addition, the research tests the nexus among corporate governance, liquidity and firm's performance. In order to reach the objectives of the study, we collect data on 80 non-financial companies listed in Pakistan Stock Exchange (PSX) over the 2010-2018 period. After excluding 17 outliers, the data of 63 companies are used to examine the relations. For analyzing the data, we apply seemingly unrelated regression equation (SURE) Model (Zellner, 1962), in which regressand is used as exogenous regressor in next equation. The variable description is shown in Table 1.

\subsection{Liquidity Measurement}

Malik, Awais and Khursheed (2016) show that the current ratio is one of the best-known and recent elements of the corporate liquidity. Current ratio is understandably connected with all types of liquid resources such as cash, marketable securities $(M / S)$, and account receivables $(A / R)$. Inventory is directly related to account receivables. The current ratio is computed as current resources available for operation divided by current liabilities needed to be paid during operation (Akben-Selcuk, 2016; Khidmat \& Rehman, 
2014). This is sometimes called accessible liquid resources. Lamberg and Valming (2009) indicated that traditionally we expect a current ratio of 2.0 , which means that the company has just about twice the maximum amount of current assets to handle the short time creditors.

\subsection{Pakistan CGI Measurement}

Different instruments of the corporate governance are designed to motivate the administration to serve the best interest of all stakeholders' particular managers, which is the core objective of a company. These instruments cover the internal and external dimensions of corporate governance mechanism. Internal dimensions are board size (BS), board meeting, CEO duality, audit committee, and independent directors of the company. The external mechanisms are the anti-takeover, procurement employment and cause interrelated rules, etc.

The Pakistan corporate governance index (PCGI) is created under the guidelines of codes of corporate governance as prescribed by the Security and Exchange Commission of Pakistan (SECP). In this study, we take the value ' 1 ' if a company ensures the criteria as specified by SECP and ' 0 ' otherwise. As an instance, if the number of company directors is more than seven, we assign the value ' 1 ' or ' 0 ' otherwise.

Table 1: Variables Description

\begin{tabular}{|c|c|c|}
\hline Variables & Calculations & Reference \\
\hline $\begin{array}{l}\text { Independent: } \\
\text { PCGI }\end{array}$ & $\begin{array}{l}\text { Index used to give } \\
\text { the value (1) if a } \\
\text { company ensures } \\
\text { the specific criteria } \\
\text { and (0) if not. }\end{array}$ & $\begin{array}{l}\text { (Javid \& Iqbal, } \\
\text { 2010; Fallatah \& } \\
\text { Dickins, 2012). }\end{array}$ \\
\hline \multirow{2}{*}{$\begin{array}{l}\text { Dependent: } \\
\text { - Return on } \\
\text { Asset (ROA) } \\
\text { - Tobin Q (TQ) }\end{array}$} & $\begin{array}{l}\text { ROA= EBTD } \div \text { Total } \\
\text { Assets }\end{array}$ & $\begin{array}{l}\text { (Khidmat \& } \\
\text { Rehman, 2014; } \\
\text { Ehiedu, 2014) }\end{array}$ \\
\hline & $\begin{array}{l}\mathrm{TQ}=\text { Equity Market } \\
\text { Value + Book value } \\
\text { of (Debt / Assets) }\end{array}$ & $\begin{array}{l}\text { (Brown \& Caylor, } \\
\text { 2006; Fallatah \& } \\
\text { Dickins, 2012). }\end{array}$ \\
\hline $\begin{array}{l}\text { Mediating: } \\
\text { - Liquidity } \\
\text { (LQDTY) } \\
\text { - Current Ratio } \\
\text { (CR) }\end{array}$ & $\begin{array}{l}\text { CR = Current Assets } \\
\div \text { Current Liabilities. }\end{array}$ & $\begin{array}{l}\text { (Khidmat \& } \\
\text { Rehman, 2014; } \\
\text { Lamberg \& } \\
\text { Valming,2009) }\end{array}$ \\
\hline \multirow{2}{*}{$\begin{array}{l}\text { Control: } \\
\text { - Leverage } \\
\text { (LEV) } \\
\text { - Firms Size } \\
\text { (FS) }\end{array}$} & $\begin{array}{l}\text { LEV }=\text { Long-term } \\
\text { Liabilities } \div \text { Total } \\
\text { Assets. }\end{array}$ & \multirow{2}{*}{$\begin{array}{l}\text { (Vu, Phan, \& } \\
\text { Dang, 2020). } \\
\text { Akbar, Polrtti- } \\
\text { Hughes, El- } \\
\text { Faitouri \& Shah, } \\
\text { 2016; Javid and } \\
\text { Iqbal, 2010). }\end{array}$} \\
\hline & $\begin{array}{l}\text { FS }=\text { Ln (Total } \\
\text { Assets) }\end{array}$ & \\
\hline
\end{tabular}

We combine all instruments to build a single composite index of corporate governance. We get the value ranging from 0 to 18 , where 0 indicates 'bad' and 18 'good' governance. Every question is grouped in a way such as, if the answer is 'yes', ' 1 ' point is added to the governance score components or ' 0 ' otherwise. These components are being used by many researchers (Javid \& Iqbal, 2010). Some other studies explore the governance-performance relation of companies listed in Karachi Stock Exchange (KSE), new name being Pakistan Stock Exchange (PSX) in the context of agency problem (Fallatah \& Dickins, 2012; Ammann, Oesch \& Schmid, 2011).

\subsection{Measurement of Mediating Variable}

It is believed that liquidity measures performance of a company including the nature of the business. However, firms with good liquidity are deemed to keep and maintain their performance and expand their business. Good performance motivates the managers to keep good governance. Therefore, liquidity is considered a good mediator between corporate performance and corporate governance.

\subsection{Econometric Models}

The study uses seemingly unrelated regression equation (SURE) as econometric models for analysis of data.

$$
\begin{aligned}
& \mathrm{LQDTY}_{i, t}=\alpha_{0}+\beta_{1} \mathrm{CG}_{i, t}+\beta_{2} \mathrm{LEV}_{i, t}+\beta_{3} \mathrm{SIZE}_{i, t}+e_{i, t}(M-1) \\
& \mathrm{ROA}_{i, t}=\alpha_{0}+\beta_{1} \mathrm{LQDTY}_{i, t}+\beta_{2} \mathrm{LEV}_{i, t}+\beta_{3} \mathrm{SIZE}_{i, t}+e_{i, t}(M-2) \\
& \mathrm{TQ}_{i, t}=\alpha_{0}+\beta_{1} \mathrm{LQDTY}_{i, t}+\beta_{2} \mathrm{LEV}_{i, t}+\beta_{3} \mathrm{SIZE}_{i, t}+e_{i, t}(M-3) \\
& \mathrm{RAO}_{i, t}=\alpha_{0}+\beta_{1} \mathrm{CG}_{i, t}+\beta_{2} \mathrm{CR}_{i, t}+\beta_{3} \mathrm{LEV}_{i, t}+\beta_{4} \mathrm{SIZE}_{i, t}+e_{i, t}(M-4) \\
& \mathrm{TQ}_{i, t}=\alpha_{0}+\beta_{1} \mathrm{CG}_{i, t}+\beta_{2} \mathrm{CR}_{i, t}+\beta_{3} \mathrm{LEV}_{i, t}+\beta_{4} \mathrm{SIZE}_{i, t}+e_{i, t}(M-5)
\end{aligned}
$$

Whereas, LQDTY is the liquidity of a firm, CG is corporate governance, LEV is firm 's leverage ratio, SIZE is firm's size, ROA is return on assets, TQ is Tobin Q and CR is Current ratio. Alpha $(\alpha)$ and Beta $(\beta)$ are the parameters and $e$ is the error term.

\subsection{Estimation Techniques}

To examine the mediating role of firm liquidity in the affiliation between governance and corporate performance, we analyze research hypotheses with simultaneous equation correlations based on seemingly unrelated regression equation (SURE) model. Bokpin and Arko (2009) introduce the linear regression model that contains of numerous regression equations, all having their own dependent variable and possibly unique sets of external variables. 
Table 2: Descriptive Statistics

\begin{tabular}{|l|c|c|c|c|c|c|}
\hline & PCGI & LQDTY & LEV & SIZE & ROA & TQ \\
\hline Mean & 14.299 & 1.6214 & 0.1397 & 16.8118 & 12.8835 & 1.1717 \\
\hline Minimum & 4.0000 & 0.1586 & 0.0000 & 13.3905 & -24.594 & 0.0481 \\
\hline Maximum & 18.0000 & 4.6120 & 0.8955 & 20.1323 & 53.1325 & 3.9769 \\
\hline Std. Dev. & 2.3584 & 0.9000 & 0.1417 & 1.4079 & 12.2259 & 0.9921 \\
\hline
\end{tabular}

\section{Results and Discussions}

We start from the descriptive statistics to analyze the data of our study. In Table 2, Pakistan corporate governance index (PCGI) averages 14.2996, while its minimum value is 4 and maximum is 18 , showing optimum spread with standard deviation 2.3584. On average, the current ratio (CR) is 1.6214, which means the firms have 1.6214-rupee assets to discharge 1-rupee current liability. The range from minimum 0.1586 to maximum 4.6120 shows handsome spread with standard deviation of 0.9000 . LEV has mean value at 0.1397 for sampled firms, while its minimum and maximum values are 0 and 0.8955 , respectively. It shows the performance of debt ratio of the non-financial firms of Pakistan with standard deviation of 0.1417 . The average natural log of SIZE is 16.8118 ranging from 13.3905 to 20.1323 with standard deviation of 1.4079. It indicates a large dispersion of data. The average earnings (ROA) of sampled firms is $12.8835 \%$. The minimum value is $-24.59 \%$ indicating a loss, and a maximum value of $53.13 \%$ indicating the highest profit of sampled firms with standard deviation 12.2259. Similarly, the mean value of TQ is 1.1717 , which ranges from 0.0481 to 3.9769 with standard deviation 0.9921 , showing little spread for the non-financial firms of Pakistan.

Table 3 presents the correlation between variables of the study. PCGI shows positive correlation as per our expectations with CR, SIZE, ROA, and TQ. It displays negative correlation with leverage ratio. Similarly, the current ratio indicates positive correlation with performance variables and negative correlation with SIZE and leverage ratio. These results also support our expectations. The strength of relationship of the above

Table 3: Correlation Analysis

\begin{tabular}{|l|c|c|c|c|c|c|}
\hline & PCGI & LQDTY & LEV & SIZE & ROA & TQ \\
\hline PCGI & 1 & & & & & \\
\hline LQDTY & 0.104 & 1 & & & & \\
\hline LEV & -0.088 & -0.314 & 1 & & & \\
\hline SIZE & 0.010 & -0.146 & 0.285 & 1 & & \\
\hline ROA & 0.093 & 0.413 & -0.238 & -0.131 & 1 & \\
\hline TQ & 0.294 & 0.336 & -0.093 & -0.131 & 0.511 & 1 \\
\hline
\end{tabular}

variables is not high, which indicates that there is no problem of multicollinearity.

Table 4 describes the outcomes of regressing the impact of PCGI on liquidity, which is measured by current ratio. The leverage ratio and SIZE are the control variables. Results indicate the positive significant effect (0.0302) of PCGI on current ratio. It implies that improvement in corporate governance mechanism would also develop the liquidity of the firm as measured by current ratio. This makes sense as the firms' governance mechanisms are sound and its management would work in the best interest of the organization's stakeholders. Tang and Wang (2011) conclude that sound governance measures would increasingly affect the liquidity of the corporation. The positive findings on the part of corporate governance and liquidity are consistent with our first hypothesis.

In Table 5, the results indicate the positive effect of liquidity on ROA. Less than $1 \%$ p-value shows the statistically significant result. It means that an increase in liquidity would enhance the ROA. These findings are consistent with the results of Ehiedu (2014), who argue that efficient maintenance of liquidity results in the smooth running of the business, which would in turn drive up the performance. As far as the matter of TQ is concerned, the effect is again positive and significant in the second column of Table 5. These outcomes are also consistent with the theories of liquidity that states that better liquidity reduces the asymmetric information and enhances the performance. The position of sound liquidity would look favorable to the investors in the stock market, which would motivate them to buy the stocks of strong liquid firms that

Table 4: Regression Results of LQDTY and PCGI

\begin{tabular}{|l|c|c|}
\hline \multicolumn{1}{|c|}{ Variables } & Coefficient & P-Value \\
\hline PCGI & 0.0302 & $0.0610^{*}$ \\
\hline LEV & -1.8354 & $0.000^{* * *}$ \\
\hline Size & 0.0417 & $0.0381^{* *}$ \\
\hline Cons. & 2.1461 & $0.0000^{* * *}$ \\
\hline R-sq. & \multicolumn{2}{|c|}{0.6086} \\
\hline
\end{tabular}

Note: The frequency Stars in parentheses is P-value $\left[{ }^{* * *},{ }^{* *},{ }^{*}\right]$ Significant at [Ten percent, five percent and one percent] levels, respectively. 
Table 5: Regression Results of Liquidity and Performance

\begin{tabular}{|l|c|c|c|c|}
\hline \multirow{2}{*}{ Variables } & \multicolumn{2}{|c|}{ ROA } & \multicolumn{2}{c|}{ TQ } \\
\cline { 2 - 5 } & Coeff. & PV & Coeff. & PV \\
\hline LQDTY & 5.0640 & $0.0000^{* * *}$ & 0.3692 & $0.0000^{* * *}$ \\
\hline LEV & -9.3777 & $0.0130^{* * *}$ & 0.2708 & $0.0950^{*}$ \\
\hline Size & -0.3962 & $0.0770^{*}$ & -0.0656 & $0.0330^{* *}$ \\
\hline Cons. & 12.6444 & $0.0410^{* *}$ & 1.6370 & $0.0020^{* * *}$ \\
\hline R-sq. & \multicolumn{3}{|c|}{0.6861} & \multicolumn{2}{c|}{0.5890} \\
\hline
\end{tabular}

Note: The frequency Stars in parentheses is P-value $\left[{ }^{* *},{ }^{* *},{ }^{*}\right]$ Significant at [Ten percent, five percent and one percent] levels, respectively.

will drive up the market value, and in turn, TQ ratio would increase (Akben-Selcuk, 2016). Khidmat and Rehman (2014) conclude that, if the current ratio is high, it usually means that the corporation is operating in a worthy and respectable position. The investors suppose that company could easily handle the cash-trouble mechanism.

Table 6 describes the regression results of the effect of PCGI on corporate performance calculated as ROA and TQ. First, PCGI shows a positive and insignificant influence on performance in terms of ROA. The p-value $(0.2560)$ indicates statistically insignificant result. It means that there is no effect of PCGI on ROA. The result is consistent with the findings observed in a study conducted by Peris et al. (2017). Other studies (Fallatah \& Dickins, 2012) investigate the relation between corporate performance and weighted index of corporate governance (WICG). They found no significant effect of WICG on corporate performance. However, they reveal a positive significant effect of WICG on TQ and market value equity. Our results are also consistent with Fallatah and Dickins (2012) when performance is measured with TQ. The co-efficient is 0.1126 while the $\mathrm{p}$ value is less than $1 \%$, indicating that corporate governance significantly improves the performance. Brown and Caylor (2006) find significant positive relation between Governance-Score TQ. These results are also consistent with our study.

Table 6: Regression Results of Performance and PCGI

\begin{tabular}{|l|c|c|c|c|}
\hline \multirow{2}{*}{ Variables } & \multicolumn{2}{|c|}{ ROA } & \multicolumn{2}{c|}{ TQ } \\
\cline { 2 - 5 } & Coeff. & PV & Coeff. & PV \\
\hline PCGI & 0.2379 & 0.2560 & 0.1127 & $0.0000^{* * *}$ \\
\hline LEV & -9.0867 & $0.0160^{* * *}$ & 0.4086 & $0.0820^{*}$ \\
\hline Size & -0.4140 & $0.0560^{* *}$ & -0.0739 & $0.0120^{* * *}$ \\
\hline Cons. & 9.5872 & $0.0550^{* *}$ & 0.1900 & $0.0720^{*}$ \\
\hline R-sq. & \multicolumn{3}{|c|}{0.6882} & \multicolumn{2}{c|}{0.6919} \\
\hline
\end{tabular}

Note: The frequency Stars in parentheses is P-value $\left[{ }^{* * *},{ }^{* *},{ }^{*}\right]$ Significant at the $[1 \%, 5 \%$ and $10 \%]$ levels, respectively.
Table 7: Results of nlcom test between ROA \& CR

\begin{tabular}{|c|c|c|c|c|}
\hline Mediating & Coeff. & SE & $Z$ & P-value \\
\hline CR & 0.1513 & 0.0826 & 1.8325 & $0.0671^{*}$ \\
\hline
\end{tabular}

Note: The frequency Stars in parentheses is P-value $\left[{ }^{* * *},{ }^{* *},{ }^{*}\right]$ Significant at the $[1 \%, 5 \%$ and $10 \%]$ levels, respectively.

The result is logical and consistent with the agency theory. The managers use to take more interest in their work when agency problem is lower. They put their interest back and work in the best of interest of the shareowners, which would also lower the agency cost, and the earnings of the firm would increase. The perspective of the agency theory considers the governance mechanism as a way to reduce the agency cost (Paminto, 2015).

Table 7 reports the results of nlcom test. This test is used to assess whether there exists mediation between current ratio (CR) and return on assets (ROA). This test confirms the significant mediation of $\mathrm{CR}$ in the relation between ROA and PCGI.

Similarly, Table 8 indicates the significant mediation of CR on the association between PCGI and performance. M-4 shows whether PCGI affects ROA whose performance is measured through current ratio. Firstly, the indirect coefficient on the part of current ratio as mediating variable is 0.1514 , which is positive and significant as $p$ value is less than $10 \%$ level of significance. M-5 shows whether CG affects TQ positively and significantly through current ratio. The indirect coefficient on the part of current ratio as mediating variable is 0.0104 , which is positive and significant as $\mathrm{p}$ value is less than $10 \%$ level of significance.

All this entails that increase in PCGI leads to increase in firm liquidity, which in turn enhances the performance based on TQ, the market measure of performance and ROA the accounting measure. Table 6 shows that the no relationship between the PCGI and ROA, significant positive relation between PCGI and TQ. It means that this liquidity's (CR) effect shows full mediation between PCGI and ROA, and partial mediated between the PCGI and TQ.

\section{Discussions and Implications}

The research purpose is to explore the mediating role of liquidity on corporate governance-performance link. In addition, the study examines the nexus between corporate

Table 8: Results of nlcom test between TQ \& CR

\begin{tabular}{|l|c|c|c|c|}
\hline Mediating & Coeff. & SE & $\mathbf{Z}$ & P-value \\
\hline CR & 0.0104 & 0.0057 & 1.8234 & $0.0690^{*}$ \\
\hline
\end{tabular}

Note: The frequency Stars in parentheses is P-value $\left[{ }^{* * *},{ }^{* *},{ }^{*}\right]$ Significant at the $[1 \%, 5 \%$ and $10 \%]$ levels, respectively. 
governance, liquidity, and firm's performance. The empirical results of the article support the mediating role of liquidity; fully mediation in case of ROA and partial mediation in case of TQ. The ROA and TQ are accounting and marketing measures of the performance. The study explains the findings in four ways. First, it finds no relation between the PCGI and $\mathrm{ROA}$ as the co-efficient is 0.2379 while the $\mathrm{p}$ value is 0.256 , indicating that corporate governance does not significantly improve the performance in Pakistan. Therefore, our results do not support hypothesis $\mathrm{H}_{1}$ when we take performance as accounting measure. The result is consistent with the studies conducted by Fallatah and Dickins (2012).

However, unlike the results of ROA, the study shows significant direct relation between the PCGI and TQ. The positive coefficient $(0.11267)$ and a $p$ value less than $1 \%$ level display direct significant relation between PCGI and TQ. In this case, the study supports H1: there is a substantial linkage between the corporate governance and the firm's performance. These very interesting results provide deep insight into the corporate affairs of the company. Accounting measure (ROA) may be effective, but is not a perfect measure of performance. It provides performance in a holistic way, considering both profit and loss statement and statement of resources of business at certain point in time. On the other side, TQ is a marketing measure. It covers all market dimensions (Zairi, 1994) including company debt. Thus, we accept our first hypothesis.

Second, the findings of this article confirm that the connection between governance of a company and its performance is significantly mediated by the inclusion of liquidity as an intervening variable. In case of ROA, we observe a fully mediating role of firm liquidity, the indirect coefficient on the part of current ratio, as mediating variable is 0.1514 , which is positive and significant as $p$ value is less than $10 \%$ level of significance. In case of TQ, we observe partially mediated effect of liquidity. The indirect coefficient on the part of current ratio as mediating variable is 0.0104 that is positive and significant as $\mathrm{p}$ value is less than $10 \%$ level of significance. The study accepts the hypothesis $\mathrm{H}_{2}$ : liquidity mediates the relation between governance of a company and its performance.

Third, the study supports the hypothesis $\mathrm{H}_{3}$ : there is an association between corporate governance of a company and its liquidity policy. The coefficient of liquidity is 0.0302 and p-value is less than $10 \%$ level of significance, confirming the result. This result is in line with Tang and Wang (2011). Fourth, the study supports the significant direct connection between liquidity and performance variables. In both cases, ROA and TQ, the study supports the hypothesis $\mathrm{H}_{4}$ : there is a linkage between liquidity and firm's performance. In case of ROA, the coefficient is 5.0640 and p-value is lower than $1 \%$ level of significance. The findings are consistent with the study by Ehiedu (2014). In case of TQ, the coefficient is
0.3692 and p-value is less than $1 \%$ level of significance. This result is consistent with studies by Akben-Selcuk (2016) and Khidmat and Rehman (2014).

The study offers expanded practical and managerial implications in the field of working capital management and corporate governance. First, the study helps to open a new channel of thinking for academics, research scholars and experts of corporate governance to understand the connection between working capital management and governance mechanism of companies. They further could develop the concepts and theories in this field. Second, the management of the company can learn and use the study in managerial tasks. Third, the policymakers and practitioners, especially the government of the Pakistan, can use this study to design policies for the non-financial sector.

\section{Conclusion and Limitations}

Overall, our study concludes that liquidity could be used to reduce the conflicts of corporate governance to increase the firm's performance; the empirical results of this study are in line with work of prior researchers (Rico \& Rohman, 2018). In the context of agency theory and asymmetric information of liquidity theory, the study opens new dimension of working capital management. This dimension is useful to resolve the issues of corporate governance suck like, disclosure, transparency and issues of auditing the companies.

The study contains some limitations that provides important directions for future research. First, whereas the study focuses on the non-financial sector, future studies could be conducted over an extended period, maybe 20-25 years, a longer time horizon may enable to generalize the results across the borders. Second, for future research, other variables could be used to mediate the relationship between governance and liquidity. The study uses TQ and ROA as performance measures. Numerous other performance variables, for instance earning per share (EPS), ROE and EVA, are available for use.

\section{References}

Achim, M.-V., Borlea, S.-N., \& Mare, C. (2016). Corporate governance and business performance: Evidence for the Romanian economy. Journal of Business Economics and Management, 17(3), 458-474. https://doi.org/10.3846/161116 99.2013.834841

Akbar, S., Poletti-Hughes, J., El-Faitouri, R., \& Shah, S. Z. A. (2016). More on the relationship between corporate governance and firm performance in the UK: Evidence from the application of generalized method of moment's estimation. Research in International Business and Finance, 38, 417-429. https://doi. org/10.1016/j.ribaf.2016.03.009

Akben-Selcuk, E. (2016). Factors Affecting Firm Competitiveness: Evidence from an Emerging Market. International Journal 
of Financial Studies, 4(2), 9-19. https://doi.org/10.3390/ ijfs4020009

Ammann, M., Oesch, D., \& Schmid, M. M. (2011). Corporate governance and firm value: International evidence. Journal of Empirical Finance, 18(1), 36-55. https://doi.org/10.1016/j. jempfin.2010.10.003

Bhagat, S., \& Bolton, B. (2008). Corporate governance and firm performance. Journal of Corporate Finance, 14(3),257-273. https://doi.org/10.1016/j.jcorpfin.2008.03.006

Bokpin, G. A., \& Arko, A. C. (2009). Ownership structure, corporate governance and capital structure decisions of firms: Empirical evidence from Ghana. Studies in Economics and Finance, 26(4), 246-256. https://doi.org/10.1108/10867370910995708

Brown, L. D., \& Caylor, M. L. (2006). Corporate governance and firm valuation. Journal of Accounting and Public Policy, 25(4), 409-434. https://doi.org/10.1108/10867370910995708

Dundek Kokotec, I., Klačmer Čalopa, M., \& Detelj, K. (2017). The Analysis of Corporative Reporting Designed to Enhance Corporate Governance: Evidence from the Banking Sector in Croatia. Zagreb International Review of Economics \& Business, 20, 59-72. https://doi.org/10.1515/zireb-2017-0005

Ehiedu, V. C. (2014). The impact of liquidity on profitability of some selected companies: The financial statement analysis (FSA) approach. Research Journal of Finance and Accounting, 5(5), 81-90. https://www.iiste.org/Journals/index.php/RJFA/ article/view/11414

Fallatah, Y., \& Dickins, D. (2012). Corporate governance and firm performance and value in Saudi Arabia. African Journal of Business Management, 6(36), 10025-10034. https://doi. org/10.5897/AJBM12.008

George, A. (1970). The Market for Lemons: Quality Uncertainty and the Market Mechanism. The Quarterly Journal of Economics, 84, 488-500. https://doi.org/10.1016/B978-0-12214850-7.50022-X

Hobdari, B., Jones, D. C., \& Mygind, N. (2010). Corporate governance and liquidity constraints: A dynamic analysis. Comparative Economic Studies, 52(1), 82-103. https://doi.org /10.1057/ces.2009.10

Javid, A. Y., \& Iqbal, R. (2010). Corporate governance in Pakistan: Corporate valuation, ownership and financing. Working Papers \& Research Reports, 2010. http:// doi. org/10.1.1.607.4669\&rep=rep1\&type $=$ pdf

Jensen, M. C., \& Meckling, W. H. (1976). Theory of the firm: Managerial behavior, agency costs and ownership structure. Journal of Financial Economics, 3(4), 305-360. https://doi. org/10.1007/978-94-009-9257-3_8

Kabir, M. U., Aripin, N. B., \& Al-Dhamari, R. A. A. (2019). Corporate Governance Mechanisms and Value Creation: An Empirical Evidence. Asian Journal of Economics, Business and Accounting, 11(4), 1-14. https://doi.org/10.9734/ajeba/2019/ v11i430134

Khidmat, W., \& Rehman, M. (2014). Impact of liquidity and solvency on profitability chemical sector of Pakistan.
Economics Management Innovation, 6(3), 34-67. http://emi. mvso.cz

Lamberg, S., \& Vålming, S. (2009). Impact of Liquidity Management on Profitability: A study of the adaption of liquidity strategies in a financial crisis. http://www.diva-portal. org $/ \mathrm{smash} /$ record.jsf?pid=diva2\%3A282882\&dswid=-4902

Lin, Y. H., Hu, S. Y., \& Chen, M. S. (2005). Managerial optimism and corporate investment: Some empirical evidence from Taiwan. Pacific-Basin Finance Journal, 13(5), 523-546. https:// doi.org/10.1016/j.pacfin.2004.12.003

Malik, M. S., Awais, M., \& Khursheed, A. (2016). Impact of Liquidity on Profitability: A Comprehensive Case of Pakistan's Private Banking Sector. International Journal of Economics and Finance, 8(3), 69-74. https://doi.org/10.5539/ijef.v8n3p69

Muhammad, H., Rehman, A. U., \& Waqas, M. (2016). The relationship between working capital management and profitability: A case study of tobacco industry of Pakistan. Journal of Asian Finance, Economics and Business, 3(2), 1320. https://doi.org/10.13106/jafeb.2016.vol3.no2.13.

Nguyen, A. H., Pham, H. T., \& Nguyen, H. T. (2020). Impact of Working Capital Management on Firm's Profitability: Empirical Evidence from Vietnam. Journal of Asian Finance, Economics and Business, 7(3), 115-125. https://doi.org/10.13106/ jafeb.2020.vol7.no3.115

Omondi, M. M., \& Muturi, W. (2013). Factors affecting the financial performance of listed companies at the Nairobi Securities Exchange in Kenya. Research Journal of Finance and Accounting, 4(15), 99-104. https://www.iiste.org/Journals/ index.php/RJFA/article/view/8309

Paminto, U. H. A. (2015). Corporate Governance and Firm Value: The Mediating Effect of Financial Performance and Firm Risk. Corporate Governance, 7(35), 18-24. http://www.raoaustralia. org/wp-content/uploads/2016/02/Corporate-Governance-andFirm-Value-The-Mediating-Effect-of-Financial-Performanceand-Firm-Risk-.pdf

Peris, R., Wandroski Peris, R., Contani, E., Contani, E., Ferreira Savoia, J. R., Ferreira Savoia, J. R., . . . Reed Bergmann, D. (2017). Does better corporate governance increase operational performance? Corporate Governance: The International Journal of Business in Society, 17(3), 524-537. https://doi. org/10.1108/CG-03-2016-0063

Perwez, U., \& Sohail, A. (2014). Forecasting of Pakistan's net electricity energy consumption on the basis of energy pathway scenarios. Energy Procedia, 61, 2403-2411. https://doi. org/10.1016/j.egypro.2014.12.015

Porter, M. E. (1992). Capital disadvantage: America's failing capital investment system. Harvard Business Review, 70(5), 65-82. https://europepmc.org/article/med/10121317

Prommin, P., Jumreornvong, S., \& Jiraporn, P. (2014). The effect of corporate governance on stock liquidity: The case of Thailand. International Review of Economics \& Finance, 32, 132-142. https://doi.org/10.1016/j.iref.2014.01.011 
Prommin, P., Jumreornvong, S., Jiraporn, P., \& Tong, S. (2016). Liquidity, ownership concentration, corporate governance, and firm value: Evidence from Thailand. Global Finance Journal, 31, 73-87. https://doi.org/10.1016/j.gfj.2016.06.006

Rajangam, N., Senderasen, S. D. D., \& Rajagopalan, U. (2014). Impact of governance on profitability, liquidity and gearing of companies. Asian Social Science, 10(10), 13-22. https://doi. org/10.5539/ass.v10n10p13

Rico, W. Z., \& Rohman, A. (2018). The effect of good corporate governance on financial performance and net working capital turnover as a mediation variable: evidence from Indonesia Stock Exchange (IDX). Journal of Business and Retail Management Research, 13(1), 70-80. https://pdfs.semanticscholar.org/d079/ cc6a9bae9b739a4423608fe7e5ee8d1f58b7.pdf

Tang, K., \& Wang, C. (2011). Corporate governance and firm liquidity: evidence from the Chinese stock market. Emerging Markets Finance and Trade, 47(1), 47-60. https://doi. org/10.2753/REE1540-496X4701S105
Valasai, G. D., Uqaili, M. A., Memon, H. R., Samoo, S. R., Mirjat, N. H., \& Harijan, K. (2017). Overcoming electricity crisis in Pakistan: A review of sustainable electricity options. Renewable and Sustainable Energy Reviews, 72, 734-745. https://doi. org/10.1016/j.rser.2017.01.097

Vu, V. T. T. Phan, N. T., \& Dang, H. N. (2020). Impacts of Ownership Structure on Systemic Risk of Listed Companies in Vietnam. Journal of Asian Finance, Economics and Business, 7(2), 107117. https://doi.org/10.13106/jafeb.2020.vol7.no2.107

Zairi, M. (1994). Measuring TQ performance in all functions. In Measuring Performance for Business Results (pp. 17-30). Springer, Dordrecht. https://doi.org/ 10.1007/978-94-0111302-1_3

Zellner, A. (1962). An efficient method of estimating seemingly unrelated regressions and tests for aggregation bias. Journal of the American Statistical Association, 57(298), 348-368. https:// doi.org/1 0.1080/01621459.1962.10480664 